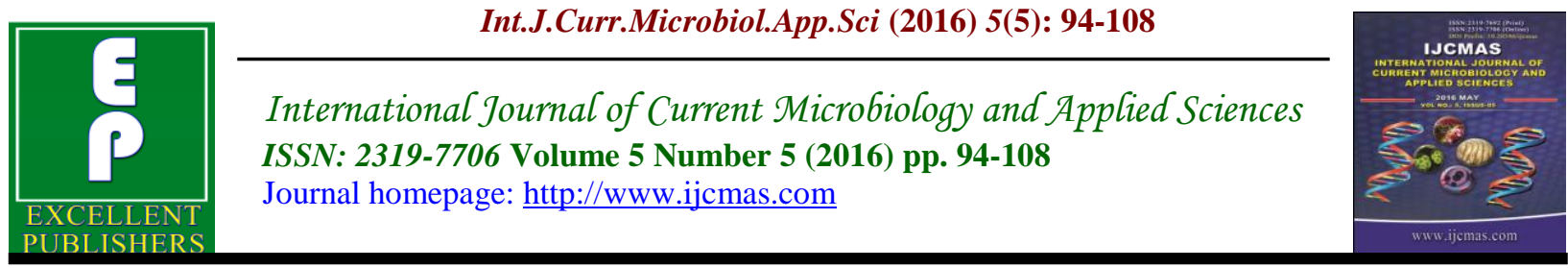

Original Research Article

http://dx.doi.org/10.20546/ijcmas.2016.505.011

\title{
Assessment of Desertification at Umm Bayada Basin (Al Maleha Locality North Darfur State - Sudan)
}

\author{
El-Abbas. Doka M. Ali ${ }^{1}$ and Mahgoub Suliman Mohamedain ${ }^{2 *}$ \\ ${ }^{1}$ Associate Professor of Soil Science, College of Agric Studies, Sudan University of \\ Science and Technology, Shambat, Sudan \\ ${ }^{2}$ Head Forestry Department, College of Forestry and Range Science, Sudan \\ University of Science and Technology, Sudan \\ *Corresponding author
}

\begin{abstract}
A B S T R A C T
Keywords

Desertification,

Umm Bayada

basin,

Land

resources,

Remote

Sensing.

\begin{tabular}{l}
\hline Article Info \\
\hline Accepted: \\
08 April 2016 \\
Available Online: \\
10 May 2016
\end{tabular}

In western Sudan including North Darfur; soil productivity is very low, where desertification results from over population in an ecologically vulnerable zone at the margins of the Sahara. In 1970-1973 drought hit this area and aggravated the situation, and its impact is still felt, not only in this area but also in Sudan as a whole (Ibrahim, 1978). The area is characterised by sand dune belts extending south north to join at $16^{\circ} \mathrm{N}$ the zone of active dune formation and it extend southwards to reach latitude $10^{\circ} \mathrm{N}$. Desertification in the same area has progressed around jebel Marra. The study indicated that the northern rocky lands, hills and mountains, dune lands and sandy pediplains are not suitable for arable farming and have poor carrying capacity for grazing. The pediplains, the basins and the erosional plains are not suitable for rainfed farming but conditionally suitable for irrigated farming with poor carrying capacity for grazing. UmmBayada basin lands are marginally to moderately suitable for rainfed farming and are moderately to highly suitable for irrigated farming. The carrying capacity for grazing is fair along the basin. Land degradation due to desertification is the main limitation for development and management of land resources. Although the area has substantial opportunities for agricultural development (mainly rangeland, forestry) nevertheless somealternative land uses should be considered benefitting from the proximity of the area to the state capital and main rural towns.
\end{abstract}

\section{Introduction}

Neither droughts nor desertification are new problems to Um Bayada area and the rest of the region for the last 100 years. Ibrahim 1984 have discussed this history and mentioned that during this time the area witnessed four droughts (i.e 1886, 1910, 1945 and 1970) and as well the reports since 1873, 1935 have indicated barrenness of the area with desert creep. Since the 1940's various attempts have been made to assess and control soil and vegetation degradation in dry savannah in Sudan. In this regard local programme like DECARP and UNSO on international level have been set for such purposes. With this recent historical record in mind, it seems that 
this continuous disastrous period have started within the last $200-300$ years ago. If the dune lands (Qoz) surrounding Um Bayada from three directions have been brought during this period, it could be estimated that the size of the original basin is five time than it is today (Figure 4). As well, it could fairly be assumed that a much denser and diversified vegetation have existed and vanished. Considerable numbers of water channels bringing in the water to the basin have also been buried.

Many remnant features around the area are standing evidences for the past wetter conditions which prevailed in the area. Although many dry stems of huge trees are scattered in the area, but very rare huge trees on depressional sites or along water channels are still surviving. Despite the dominance of the short and dwarf thorn species adapted to the drought, but even these at the present are under more stress conditions and eventually might disappear as well with no chances for any vegetation to regenerate. During these persistent dry, windy conditions, the shrubs start to develop hummocks which gradually surround them with sands and eventually the bushes get killed as there is no chance to get a bit of a humid air at night or moist roots during the rare drops of rain water. As for the big trees (Figure 6) they survive the droughty conditions for longer period. They continue exploiting soil moisture through the extended root system and when this moisture decreases big branches start to die one by one until it come to main stem which is the last part to collapse (Figure 7). In protected areas where there is little chance for hummocks to develop, the bushes and small trees could die through this method of soil moisture depletion. Features and remnants of old flat depressions, lacustrines and lakes were also being noticed in some parts indicating the past wetter conditions
(Figure 8). Many patchy clusters of shells of different sizes were encountered at the north eastern depressions. It seems that a big lake with back swamps used to exist in this part where a huge wadi course system ends up here. Artefacts of different types like broken pottery and grain grinding stones were found scattered especially beside upper hill slopes on the edge of the basin. The selection of such locations for villages and residence could be attributed to the prolonged flooding conditions down the basin.

\section{Materials and Methods}

\section{Materials}

\section{Study Area Location and General Features}

The study area is located in North Darfur State, north east of Al-Fasher the state capital and lies within Malha Locality. The main road which connects Al-Fasher to Hamrat AlSheikh in North Kordofan runs across Um Bayada area. The presence of Al-Meidoub dome and associated subsequent uplifts, have influenced local and regional sequence of land formation and degradation (Figure 1 and 2). The Southern foreland of Jebel Meidoub dome is drained mainly by Wadi Mogran, Angro, Seyal, Bado, Forgan, Shaw, Owr and Kabish and their main tributaries. These Wadis contribute to the huge annual discharge which is estimated to be about $3-5 \mathrm{Mm}^{3}$. Administratively the area belongs to $\mathrm{Al}$ Maliha locality.

The local population are mainly sedentarists and semi-nomadic residing in small scattered villages and huts. The area as well includes some nomadic tribes from neighbouring regions. Most of the sedentary population practice subsistence agriculture, with some keeping livestock plus other minor activities. 


\section{Methods}

\section{Definitions of Desertification}

The United Nations Conference on Environment and Development (UNCED, 1992) defined the desertification as "land degradation in arid, semi-arid and dry subhumid areas resulting from various factors, including climatic variations and human activities ". This definition was adopted by the United Nations Convention to Combat Desertification (UNCCD) in 1994, and it is adopted in this study.

\section{Desertification in Sudan}

In 1976 the Sudan's Desert Encroachment Control and Rehabilitation Program (DECARP) concluded, "it appears that no one single factor causes desertification. Obviously, it is a combination of factors, involving fragile ecosystem, developed under harsh and fluctuating climate, and man's activities, some of which are increased in irreversible magnitude by weather fluctuations, especially periodic drought". Reduction in canopy cover in old fallow lands, range lands and forests, is more significant in northern Sudan, due to rapid increase in population coupled with high rates of land clearing.

Dixey and Aubert (1962) estimated the advance of the sand dunes encroachment in some agricultural land in Sudan to be at rate of 1 to 3 meters per year. Awouda, (1985), quoting from DECARP (1976) estimated the Sudan Deserts movement to be at rate of 5 to $6 \mathrm{Km}$ per year, threatening all Nile irrigation schemes in northern and central Sudan and being man induced. According to DECARP (1976), the most important features of Desertification in Sudan, which have been aggravated by the drought, are:
a.Man made land misuse due to overgrazing, irrational cultivation, wood cutting and deforestation.

b.Cultivation of marginal areas.

c.Land clearance for cultivation expansion

d.Declining food production.

In western Sudan (North and South Darfur; North and South Kordofan) soil productivity is very low, where Desertification results from over population of an ecologically vulnerable zone at the margins of the Sahara. In 1970-1973 drought hit this area and aggravated the situation, and its impact is still felt, not only in this area but also in Sudan as a whole (Ibrahim, 1978). The area is characterised by sand dune belts extending south north to join at $16^{\circ} \mathrm{N}$ the zone of active dune formation. Its southern extension reaches latitude $10^{\circ} \mathrm{N}$ beyond Bahr El Arab (Bakhit and Ibrahim, 1982). Desertification in the same area has progressed around jebel Marra. Nomads lost their formerly good pasture in the Qoz of Jebel Marra in Darfur and moved to other areas with increasing frequency (Akhtar et al., 1994).

In north Sudan, sand encroachment threatens all Nile irrigation schemes, about 2.3 million Feddans of pumps scheme and 7 million Feddans of mechanised crop farming (Awouda, 1985). Awouda quoting from a UNEP/UNESCO reconnaissance team indicates that the situation of sand movement in north Sudan is alarming. Wadi Hawar was already buried by sand. Along the Nile between Delgo and Karima, sand is approaching the north-facing bank and already the sand has reached the Nile. Sand dunes are on their way to the other agricultural lands and villages. 


\section{Results and Discussion}

\section{Present situation}

\section{Soil Degradation (Wind Erosion)}

The main soil types at Um Bayada which are vulnerable to wind erosion are:

\section{Clayey soils}

2. Sandy soils (Sand sheets; Stabilized Qoz and Mobile Qoz)

The present decreasing alluvium soils in Um Bayada basin represent the remaining part of the extensive cracking clay soils which have been buried under the creeping sands. The winds are continuously taking the fine soil materials and as well depositing relatively heavy fine and medium sand grains. Continuous and patchy thick and thin over blown sands cover most parts of the basin and only limited depressional strip of the basin is left without overblown sand. The Sand sheets and stabilized Qoz are basically aeolian features composed mainly of sand materials that are blown, deposited and shaped by wind action. During favourable climatic conditions different types of vegetation grow and protect these fragile land surfaces. Due to the prevailing droughty weather conditions aggravated by man the lands start to lose their vegetation cover and hence exposed to wind blowing which strip off the topsoil rich in organic matter

\section{Vegetation Degradation}

Although the reduction in plant cover densities $\%$ is usually comes first when assessing vegetation degradation, but the following aspects in vegetation could also be monitored to detect the changes during long periods:
Adverse change in plant associations

Increase or decrease of grass, herbaceous and palatable species

Clearing for cultivation and other purposes

Overgrazing and overstocking

Qoz Taroum, the destruction of the vegetation similar to that usually done by a tornado that passed across the area. In the tornado case the people try to strengthen their homes to survive until it passes, but at dry lands people unintentionally help desertification to inflict more damage and stay longer.

The status of desertification reflected in the above photograph represents the situation at the stabilized dunes and demonstrate clearly that the prevailing drought is the main driving force behind desertification at $\mathrm{Al}$ Meidob area. The less evident human impact in the area could be attributed to the scarcely populated land coupled with limited number of goats, sheep and camels. Due to the persistent drought most people have left the area and those who are staying are keeping very few animals for domestic purposes.

\section{Desertification Limitations on Grazing and Millet Growing}

The grazing lands at Um Bayada have witnessed both vegetation degradation and sand encroachment. The seasonal extensive rangelands which used to provide palatable grasses and browsing trees for the animals of Al Meidob and their neighbouring pastoralists $\mathrm{Al}$ Kababish and other tribes have turned to be very poor. Limited camels, goats and sheep owned by sedentary villagers are now surviving on few scattered bushes growing on the Wadis and on hills slopes flanking the basin. 
The widely practiced traditional subsistence farming of rainfed millet is now confined to limited areas of nearly flat sand plains or slightly depressional sites close to the mountains. Most the frequent crop failures are due to moisture deficiency caused by drought and the unfavourable soil moisture conditions caused by desertification. Desertification have created harsh environmental conditions and contributed in creating local conflicts and civil wars. This situation has forced many inhabitants to leave their homes and settle else looking for safe heaven. Vegetation degradation is reflected in density of biomass, the dominant species and even in the size and type of dead trees and bushes. At stabilized Qoz lands very few scattered trees still surviving but the destructed dry trees cover the whole landscape. At the mobile dune lands the desertification processes are intensive and persistent to the extent that they have completely stripped their vegetation and grasses. Aeolian features and their patterns normally dominate reflectance seen in Satellite imageries.

Sand accumulation or desert encroachment is usually affected by wind direction and accordingly at high reflectance areas of Landsat images elongated pattern of longitudinal dunes are clearly seen especially at mobile dune areas. As for soil erosion it dominates the low lands of the basin especially those bordering the hills where variable thicknesses of overblown sands start to mask the surfaces of the clay materials. Soil degradation is reflected in the localized sealed surfaces caused by water erosion during rainy season. Salinization is expected to exist in basin lands and also no reflection is seen on the surfaces but most probably it might develop after cultivation basin lands.

Although the winds and sand storms are accelerated by the presence of $\mathrm{Al}$ Meidob hills, but the existence of slightly elevated parts inside the basin slow down their movement and consequently depositing the sand materials on top of the slightly elevated parts. The thick overblown materials on top of the clays are often formed this way. Local winds and eddies travelling for short distances within the basin usually deposit their sand loads inside the basin and form thin over blown materials on the top of the cracking clay soils of the basin.

\section{Assessment of Desertification Hazards at Different Land Forms}

\section{Status of Desertification}

The delineated interpreted units were related to land use in order to assess the impact of man on his environment. Then they were evaluated, with respect to desertification, according to FAO/ UNEP Provisional Methodology for Assessment and Mapping of Desertification, (1983/84). Following the norms and criteria proposed by this methodology, two processes of desertification were found to dominate the study area:

\section{Vegetation Degradation}

\section{Wind Erosion (Sand Accumulation)}

The estimation of vegetation density as indicator of vegetation degradation was based on the premise that the amount of active photosynthesis increases with increasing density. Therefore, an increased intensity towards red on the FCC generally means denser vegetation. The sparser vegetation tends to be grassy and dead and hence appears yellowish on FCC. Whenever no red or yellow is visible on FCC, vegetation is regarded absent or very sparse. Estimation of wind erosion extent was indicated by presence of active wind erosional or depositional forms like sand 
sheets, dunes or hummocks and evidenced by their light color (resulting from lush reflectance).

After the estimation of vegetation degradation and Aeolian coverage, the intensity of each of the two processes was classified into 4 distinct classes of desertification: None to Slight, Moderate, Severe and Very Severe, table (3.2).

\section{Rate of Desertification}

An attempt was done to compare status of desertification for both periods (1986 and 2000) for the Qozland, Basins and Highlands. The differences between the two situations reflect the amount of change or the rate of desertification.

Although the highlands are considered as part of the main deflation areas, but their dissected rugged surfaces used to affect wind, sand storms and create eddies leading to deposition of fine sands on High hill sides (Southern aspects) at the upper Wadi systems and valley bottoms. If this trend continues the Wadi system will be buried by the accumulating sands and eventually this will affect the amount of Wadi seasonal water. Overblown sands accumulated at upper slope and carried down by water inside the Wadi.

The situation here is very much affected by the intensity of the desert sand storm blowing from the northern Meidob sandy plains due to the intense arid conditions aggravated by the continuous droughts. The vegetation which is composed of tall trees and bushes was rarely affected by cutting and impact by man as it is the only grazing ground for the camels, sheep and goats which belong to local villagers.

The increasing accumulation of the very fine sand grains might block the fissures and cracks on the valleys and Wadis and eventually slow the seepage of water into the pervious strata which feed many spring around the highlands (e.g. Shakhakha spring).

It is evident from above photograph that continuous accumulation of the sands will result in considerable changes in the topographical characteristic of the wadi. This will affect the seasonal water flow patterns of the wadi and results in more sands being carried down the Wadis making the alluvium deposits sandier and droughtier for cereal crops.

Thin $(<10 \mathrm{~cm})$ and thick $(10-25 \mathrm{~cm})$ overblown sandy layers have covered large parts of the basin masking the surfaces of the cracking clays especially at the northern and middle parts. Thick overblown deposits will definitely affect topsoil properties as related to moisture content and nutrients qualities. The overblown sandy top soils have very low moisture retention characteristics and can only support the establishment of grasses during the short rainy season of the area. Since they also fill the cracks of the clays, they leave little chance for the water to penetrate through cracks and moist the clays. With the continuous drought the clays become more desiccated and gradually are depleted of the residual moisture.

The overblown sands which are in continuous move (encroachment) as affected by local eddies inside the basin are rapidly increasing due to the addition of more sands blown over the highlands and deposited within the basin.

This situation has to be halted at this stage as it might be very difficult and costly to cultivate and manage the potential farming lands at Um Bayada. Irrigation systems, machines, building and topsoil need to be monitored on daily bases. In most situations, the cleared sands need to be collected and moved away. 
Table.1 Influence of Drought, Grazing, Fire, Crop-Cultivation and Woodcutting on Canopy Cover Per-Climate Zone

\begin{tabular}{|c|c|c|c|c|}
\hline Factor & $\begin{array}{l}\text { Northern } \\
\text { Sahel }\end{array}$ & $\begin{array}{l}\text { Southern } \\
\text { Sahel }\end{array}$ & $\begin{array}{l}\text { Northern } \\
\text { Sudan }\end{array}$ & $\begin{array}{l}\text { South } \\
\text { Sudan }\end{array}$ \\
\hline Drought & +Negative & +Negative & Negative & Zero \\
\hline Grazing & Negative & *Positive & Positive & Positive \\
\hline Fire & No material & Negative & Negative & Negative \\
\hline $\begin{array}{l}\text { Crop } \\
\text { cultivation } \mathrm{T}\end{array}$ & Zero & $\begin{array}{l}\text { Zero/ } \\
\text { Negative }\end{array}$ & $\begin{array}{l}\text { Zero/ } \\
\text { Negative }\end{array}$ & $\begin{array}{l}\text { Zero/ } \\
\text { Negative }\end{array}$ \\
\hline cultivation $\mathrm{M}$ & Zero & +Negative & +Negative & +Negative \\
\hline Wood cutting & Negative & +Negative & +Negative & +Negative \\
\hline
\end{tabular}

Influence is indicated as follows:

Positive: positive influence; Negative: negative influence; +Negative: very negative influence; ${ }^{*}$ Negative: depending on the soil type; Zero: no influence, occur; $\underline{\mathrm{T}}$ : traditional (extensive); $\underline{\mathrm{M}}$ : modern (intensive)

(Source: Breman and Kessler 1995)

Table.2 Criteria for Assessing the Status of Vegetation Degradation and Sand Accumulation

\begin{tabular}{|l|l|l|l|l|l|}
\hline Process & $\begin{array}{l}\text { Assessment } \\
\text { Factors }\end{array}$ & \multicolumn{3}{|c|}{ Class limits } \\
\cline { 3 - 6 } & Sone to & Moderate & Severe & $\begin{array}{l}\text { Very } \\
\text { Severe }\end{array}$ \\
\hline $\begin{array}{l}\text { Degradation of } \\
\begin{array}{l}\text { Vegetation } \\
\text { cover }\end{array}\end{array}$ & $\begin{array}{l}\text { Vegetation } \\
\text { Density \% }\end{array}$ & $>50$ & $20-50$ & $5-20$ & $<5$ \\
\hline $\begin{array}{l}\text { Sand } \\
\text { Accumulation }\end{array}$ & $\begin{array}{l}\text { Surface Area } \\
\text { Covered by } \\
\text { Sand } \\
\text { sheet, Dunes } \\
\text { or } \\
\text { hummocks }\end{array}$ & $<5$ & $5-15$ & $15-30$ & $>30$ \\
\hline Desertification Class & 1 & 2 & 3 & 4 \\
\hline
\end{tabular}

Source: The FAO/UNEP Provisional Methodology for Assessment and Mapping of Desertification, (1983/84)

Table.3 Criteria for Assessing Rate of the Desertification

\begin{tabular}{|l|l|l|l|l|l|c|}
\hline Process & $\begin{array}{l}\text { Desert- } \\
\text { ification } \\
\text { aspect }\end{array}$ & $\begin{array}{l}\text { Assess- } \\
\text { ment } \\
\text { factor }\end{array}$ & $\begin{array}{l}\text { None } \\
\text { to } \\
\text { slight }\end{array}$ & $\begin{array}{l}\text { Mode- } \\
\text { rate }\end{array}$ & Severe & $\begin{array}{l}\text { Very } \\
\text { severe }\end{array}$ \\
\hline $\begin{array}{l}\text { Degradation } \\
\text { of } \\
\text { vegetation } \\
\text { cover }\end{array}$ & Rate & $\begin{array}{l}\text { Degrad- } \\
\text { ation } \\
\text { increment } \\
(\% / y e a r)\end{array}$ & $<1$ & $1-2$ & $2-5$ & $>5$ \\
\hline $\begin{array}{l}\text { Wind } \\
\text { Erosion }\end{array}$ & Rate & $\begin{array}{l}\text { Increase in } \\
\text { Area(\%/year) }\end{array}$ & $<1$ & $1-2$ & $2-5$ & $>5$ \\
\hline \multicolumn{2}{|l|}{ Desertification Class } & & 1 & 2 & 3 & 4 \\
\hline
\end{tabular}

Source: The FAO/ UNEP Provisional Methodology for Assessment and Mapping of

Desertification, (1983/84) 
Table.4 Assessing Desertification at Highlands

\begin{tabular}{|l|c|c|c|c|c|c|c|c|}
\hline Type & \multicolumn{2}{|c|}{ Status of Desertification } & \multicolumn{2}{|c|}{ Rate of Desertification } \\
\hline Indicator & \multicolumn{2}{|c|}{$\begin{array}{c}\text { Vegetation } \\
\text { Degradation }\end{array}$} & \multicolumn{2}{c|}{$\begin{array}{c}\text { Sand } \\
\text { Accumulation }\end{array}$} & \multicolumn{2}{|c|}{$\begin{array}{c}\text { Vegetation } \\
\text { Degradation }\end{array}$} & \multicolumn{2}{c|}{$\begin{array}{c}\text { Sand } \\
\text { Accumulation }\end{array}$} \\
\hline Intensity & Level & Class & Level & Class & Level & Class & level & Class \\
\hline $\begin{array}{l}\text { High } \\
\text { Lands } \\
\text { (Jebels) }\end{array}$ & $\begin{array}{c}\text { Mode- } \\
\text { rate }\end{array}$ & 2 & $\begin{array}{c}\text { None } \\
\text { to } \\
\text { Slight }\end{array}$ & 1 & $\begin{array}{c}\text { Mode } \\
\text { rate }\end{array}$ & 2 & $\begin{array}{c}\text { Mode } \\
\text { rate }\end{array}$ & 2 \\
\hline
\end{tabular}

Table.5 Assessing Desertification at Low lands

\begin{tabular}{|l|l|c|c|c|c|c|c|c|}
\hline Type & \multicolumn{2}{|l|}{ Status of Desertification } & \multicolumn{2}{c|}{ Rate of Desertification } \\
\hline Indicator & \multicolumn{2}{|c|}{$\begin{array}{c}\text { Vegetation } \\
\text { Degradation }\end{array}$} & \multicolumn{2}{|c|}{$\begin{array}{c}\text { Sand } \\
\text { Accumulation }\end{array}$} & \multicolumn{2}{|c|}{$\begin{array}{c}\text { Vegetation } \\
\text { Degradation }\end{array}$} & \multicolumn{2}{c|}{$\begin{array}{c}\text { Sand } \\
\text { Accumulation }\end{array}$} \\
\hline Intensity & Level & Class & Level & Class & Level & Class & level & Class \\
\hline $\begin{array}{l}\text { Low } \\
\text { Lands } \\
\text { (Basin) }\end{array}$ & $\begin{array}{l}\text { Very } \\
\text { Severe }\end{array}$ & 4 & $\begin{array}{c}\text { None } \\
\text { to } \\
\text { Slight }\end{array}$ & 1 & $\begin{array}{c}\text { Very } \\
\text { severe }\end{array}$ & 4 & $\begin{array}{c}\text { Mode } \\
\text {-rate }\end{array}$ & 2 \\
\hline
\end{tabular}

Table.6 Assessing Desertification at Qoz Lands

\begin{tabular}{|l|l|l|l|l|l|l|l|l|}
\hline Type & \multicolumn{2}{|l|}{ Status of Desertification } & \multicolumn{2}{|c|}{ Rate of } & \multicolumn{2}{c|}{ Desertification } \\
\hline Indicator & \multicolumn{2}{|c|}{$\begin{array}{c}\text { Vegetation } \\
\text { Degradation }\end{array}$} & \multicolumn{2}{|c|}{$\begin{array}{c}\text { Sand } \\
\text { Accumulation }\end{array}$} & $\begin{array}{c}\text { Vegetation } \\
\text { Degradation }\end{array}$ & $\begin{array}{c}\text { Sand } \\
\text { Accumulation }\end{array}$ \\
\hline Intensity & Level & Class & Level & Class & Level & Class & level & Class \\
\hline Qoz Land & $\begin{array}{l}\text { Very } \\
\text { severe }\end{array}$ & 4 & $\begin{array}{l}\text { Very } \\
\text { Severe }\end{array}$ & 4 & $\begin{array}{l}\text { Very } \\
\text { severe }\end{array}$ & 4 & $\begin{array}{l}\text { Very } \\
\text { severe }\end{array}$ & 4 \\
\hline
\end{tabular}

Figure.1 El Meidob Hills and Umm Bayada Area

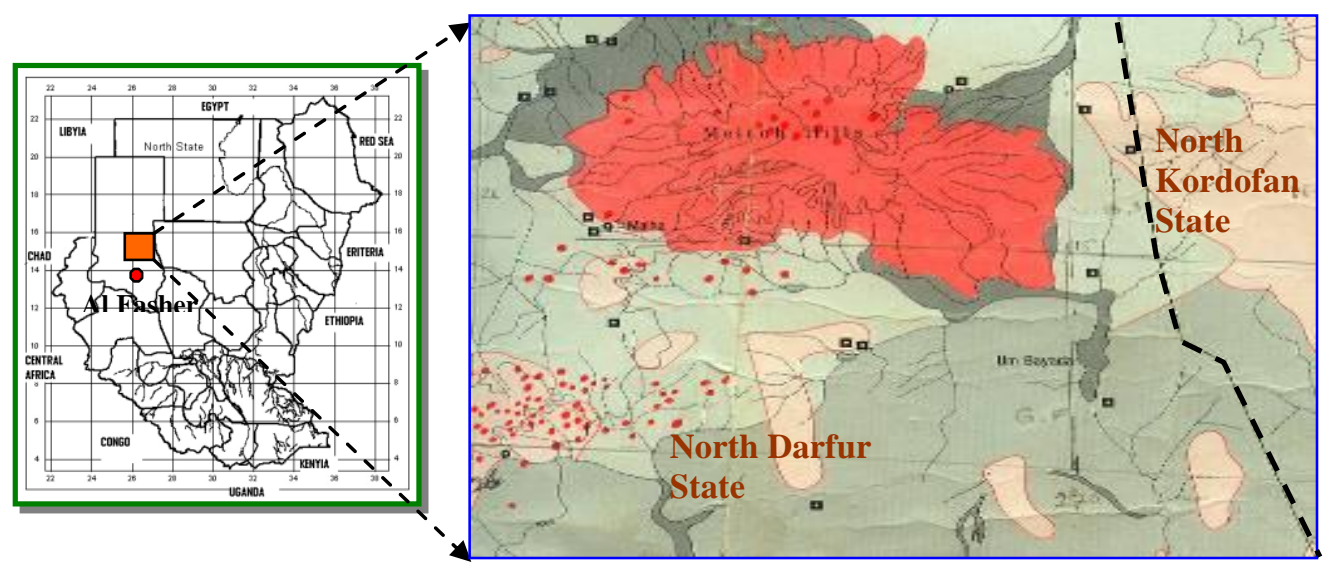


Figure.2 The Extent of the Old and Present Umm Bayada Basin on Landsat Images

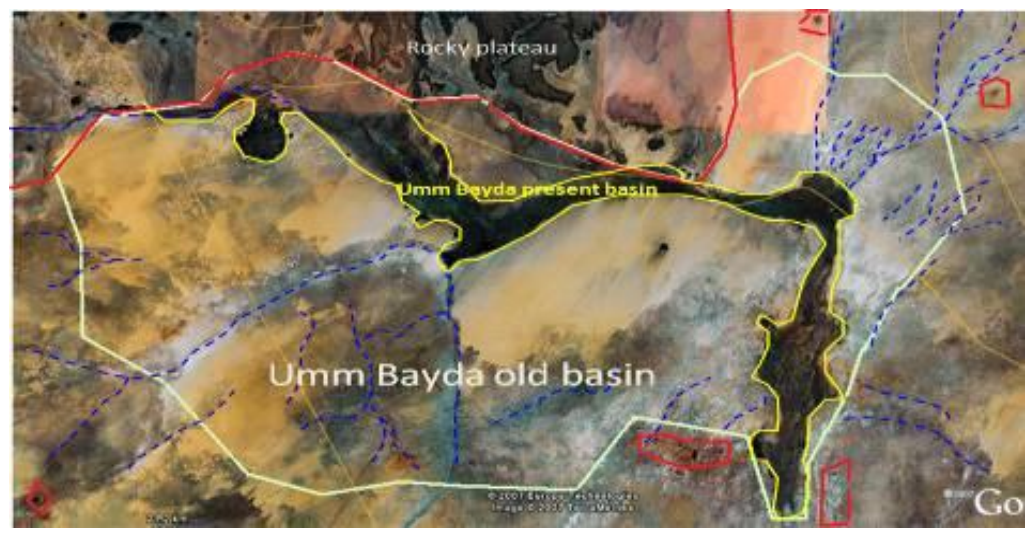

Figure.3 Overblown Sands on Mulchy Clay Soils of the Sloping Land at the Northern Edge of Um Bayada Basin with very Poor Vegetation Cover

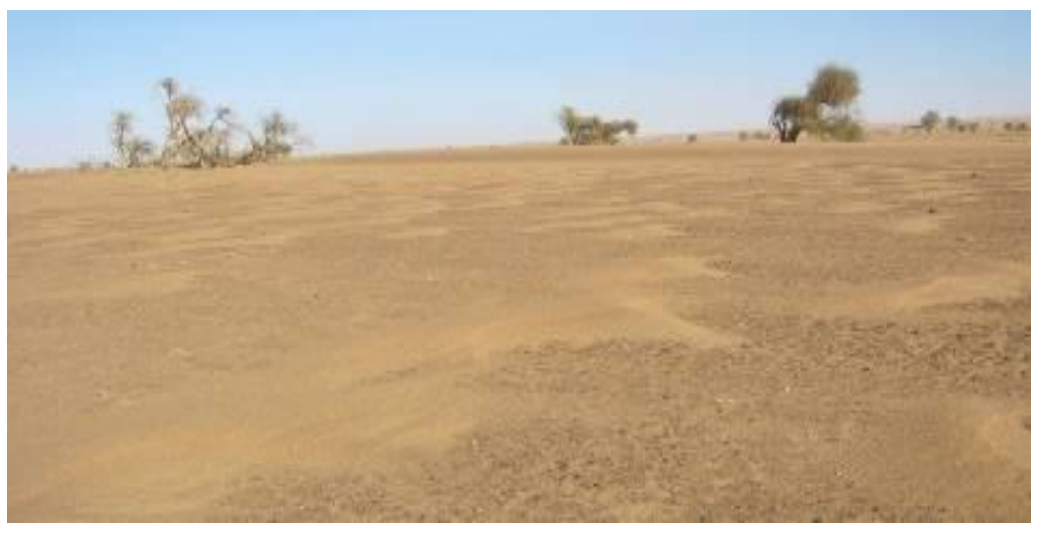

Figure.4 The Destruction of the Vegetation Qoz Taroum (North East Um Bayada)

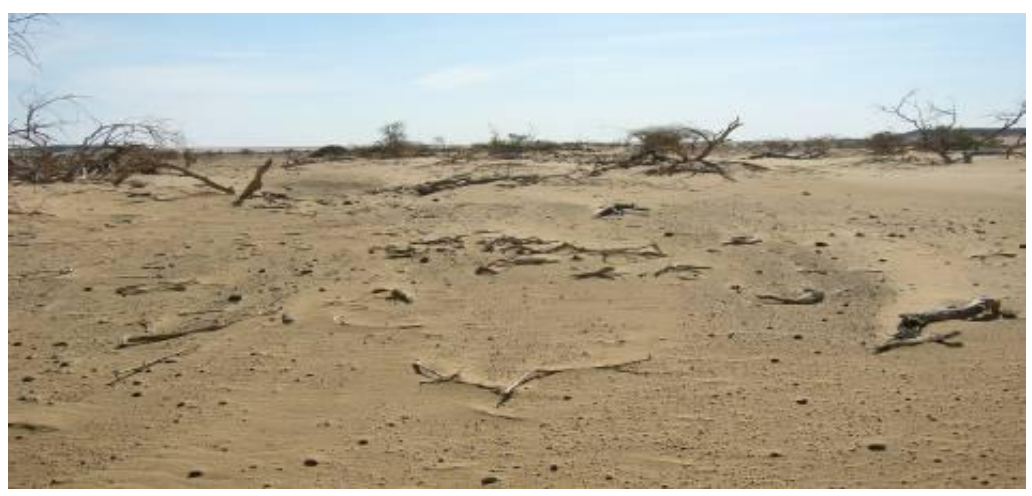


Figure.5 A Selected Transect from Point A to B to Explain Desertification Processes (i.e. the Schematic Diagram)

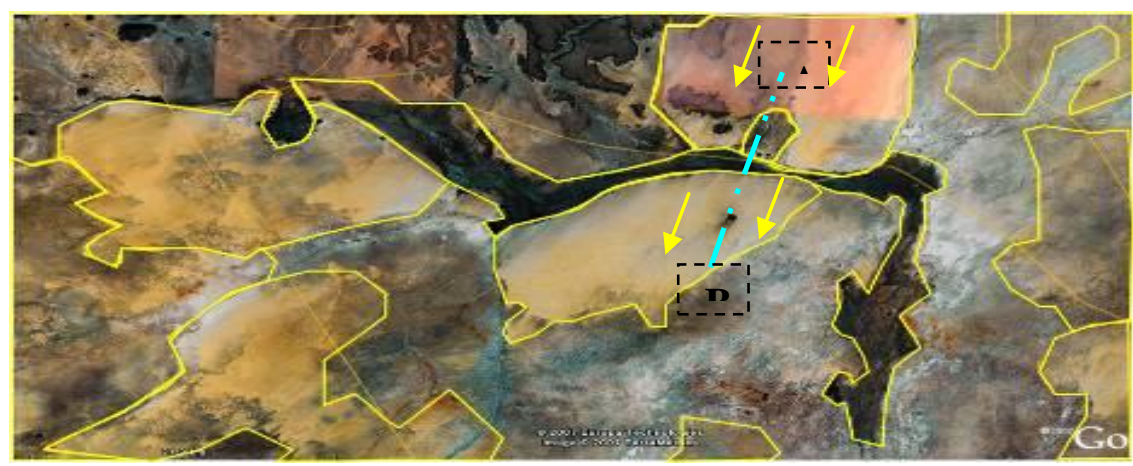

Figure.6 Schematic Diagram Across Um Bayada Area (N-S) Showing Qozland Formation Processes \& Related

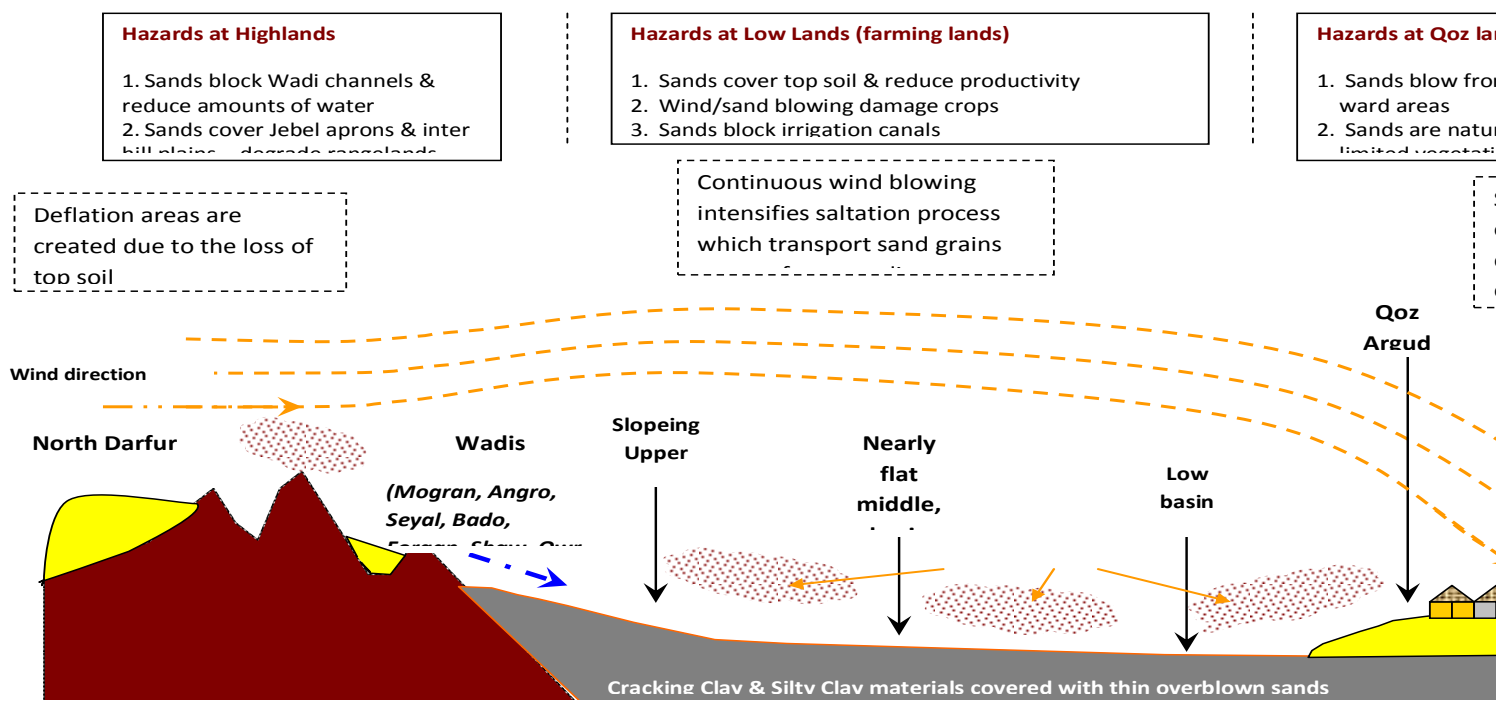

Figure 14: Schematic diagram across Um Bayada area (N-S) showing Qozland formation processes \& related haza

Figure.7 Sand Accumulation Accelerated by the Presence of Highlands (Meidob Hills)

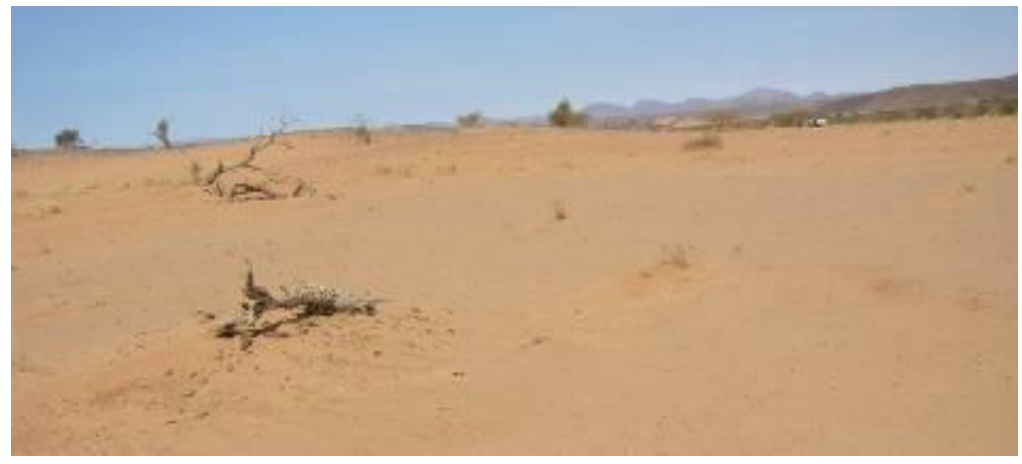


The Extent of Aeolian Features with the Prevailing Wind Blowing Directions at Umm Bayda. (Landsat TM 2000)

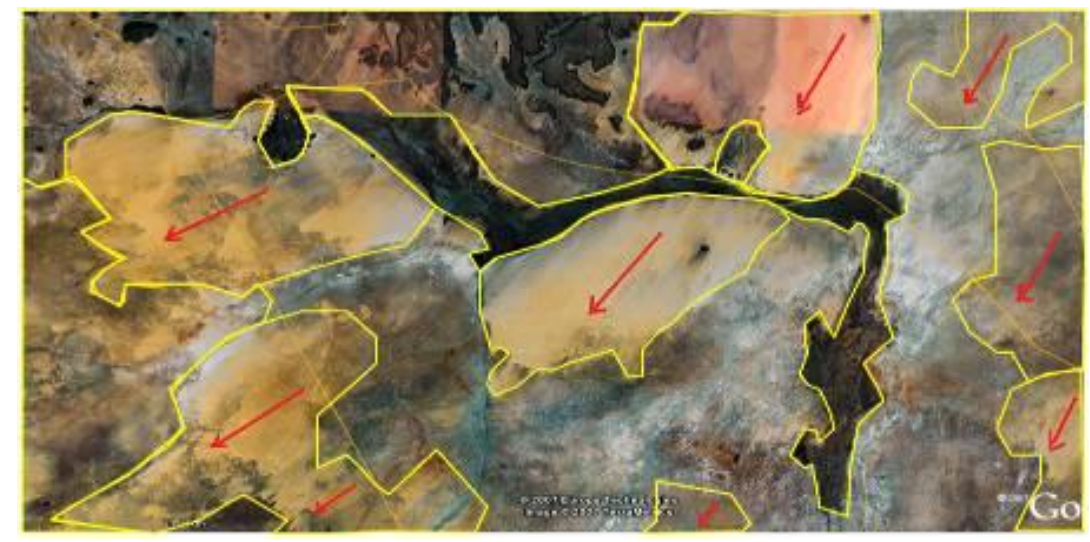

a- $\quad$ Highlands (Jebels Bordering Plains and Basins)

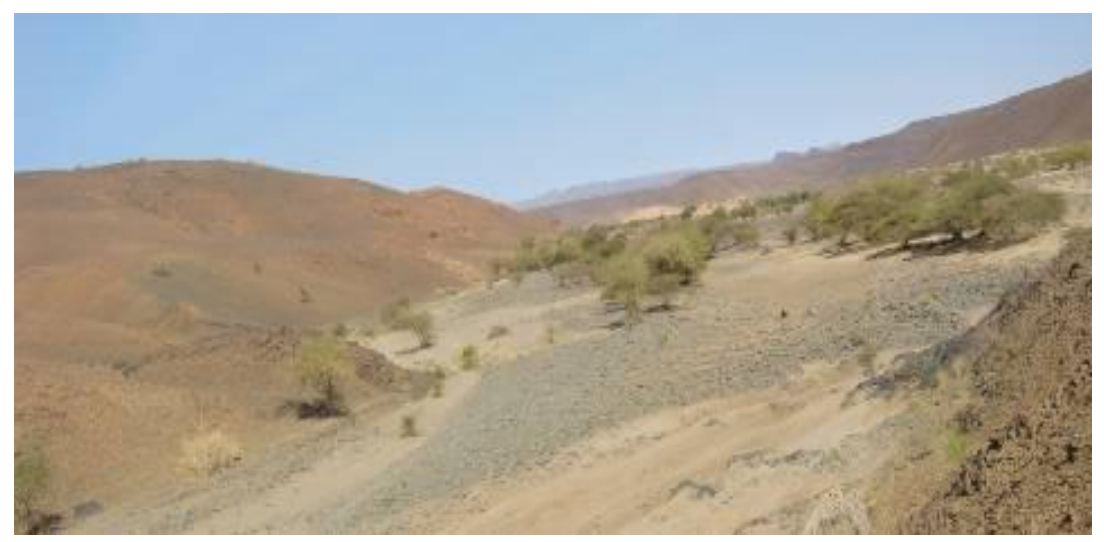

Figure.8 The Wadis in the Area Receives the Overblown Sands beside the Sands carried by Water. Sands are also on Top of some Low Hills Surrounding this Wadi

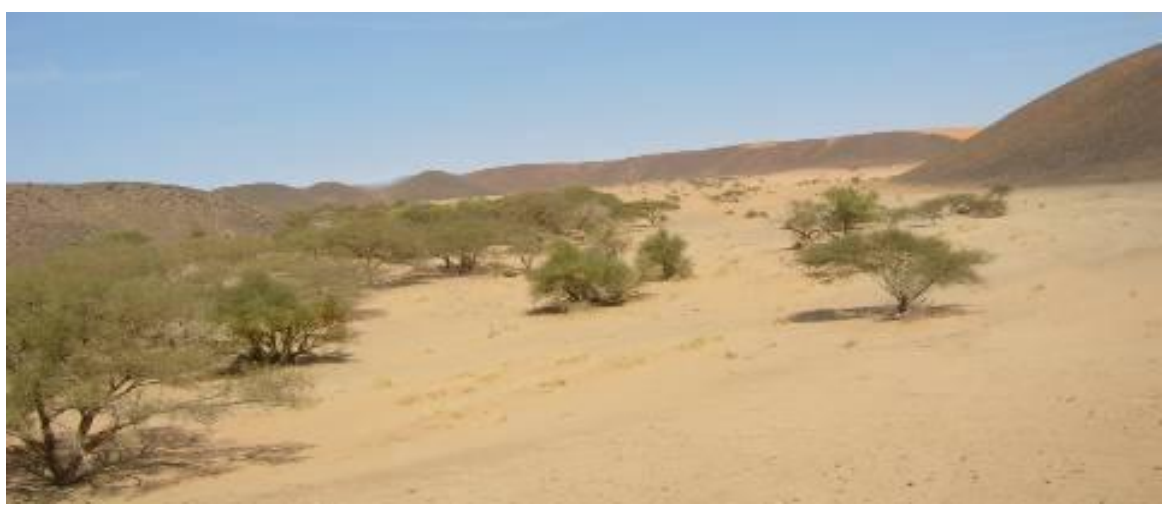


Figure.9 Thin Overblown Sands Masking the Clays at Some Parts of the Basin

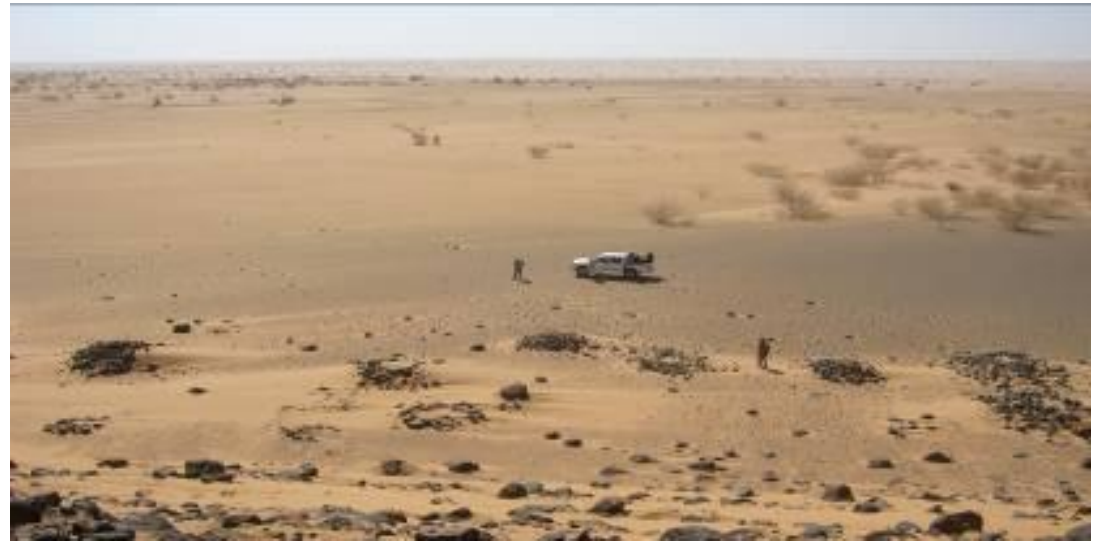

Figure.10 The Cracking Clays are Completely Covered by Thin and Thick Overblown Sands

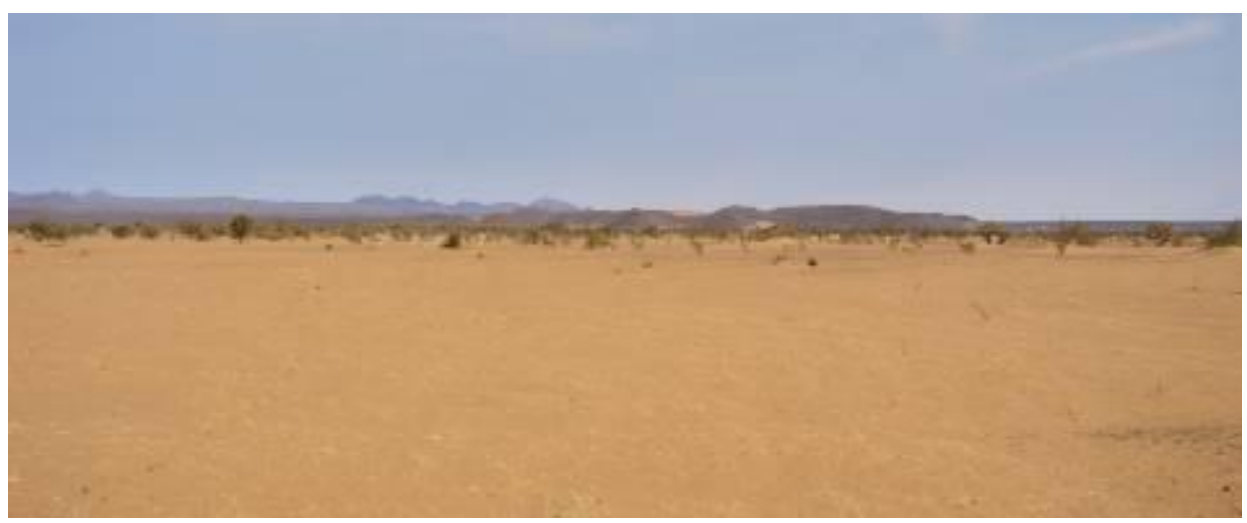

Figure.11 Dune Lands (Qoz and Sandy Plains)

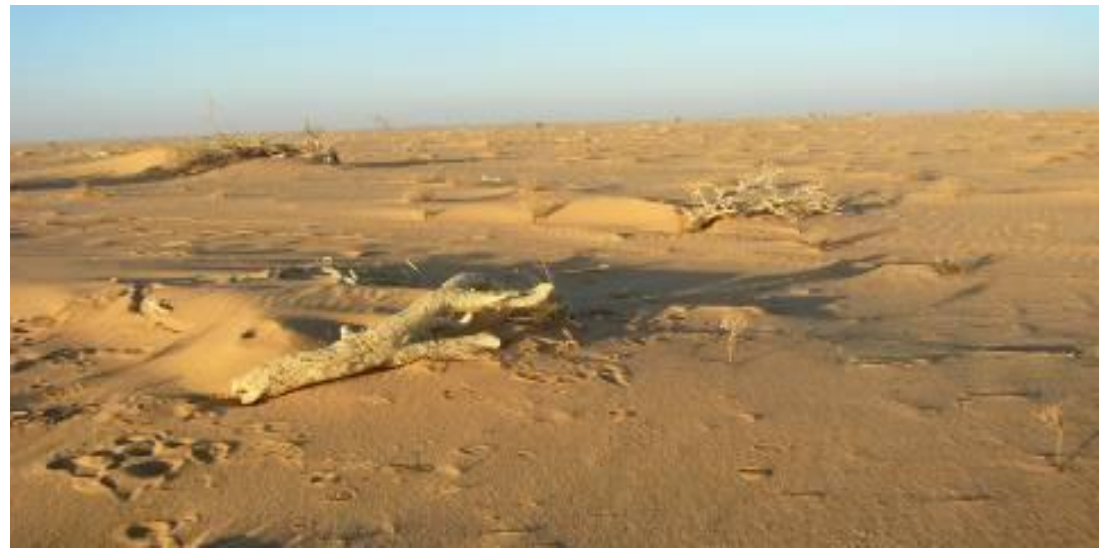




\section{Figure.12 Priorities for Combating Desertification at Umm Bayad}

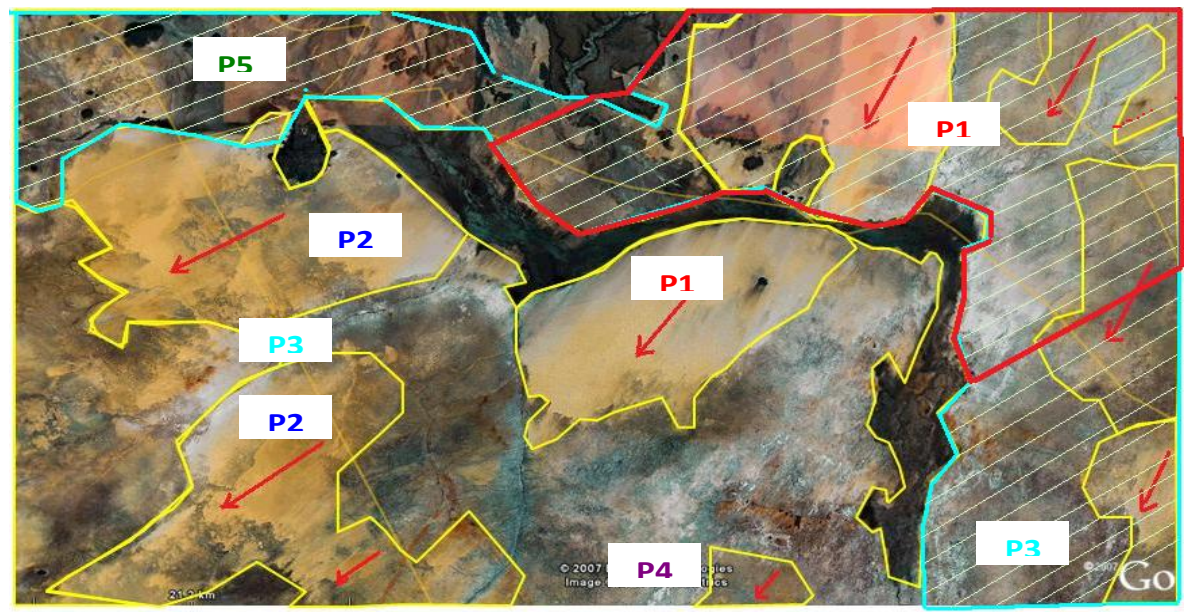

The Qoz lands enclose Um Bayada basin from all directions except the northern which is occupied by $\mathrm{Al}$ Meidob hills. It seems that the slightly elevated parts at the southern, western and eastern parts of the old basin encourage the formation of the present Qoz lands (Qoz Argud, Graywid and the Qoz lands near Mariga). Limited parts of these Qozlands are stabilized but the main parts are completely stripped of the vegetation and now the sands are actively moving.

The desertification processes are at their maximum strength to the extent that even seasonal grasses might not find it favourable to regenerate. Regenerating bushes and tree might be impossible at these stages without halting sand movement.

In conclusion, due to the regional drought and aridity conditions $\mathrm{Al}$ Meidob area is under high pressure from pastoralists coming from neighboring tribes. The area lost major parts of it vegetation cover and the sand accumulation is threatening the highly suitable basin lands for agricultural production.

Sand accumulation at residential areas reached disastrous levels. Homes, schools, public service buildings were all surrounded and/or covered with huge piles of sand. Sand accumulation has to be cleared on daily bases otherwise it buries any kind of obstruction in a matter of days.

Qoz land reaches highest level of desertification severity and stand as the most critical situations which call for immediate action.

Basin lands although most of its parts not affected by sand accumulation and presently are at the lowest desertification severity but vegetation degradation reaches its maximum severity and it needs immediate attention.

The Highlands as such do not stand any concern in relation to both desertification processes, but the Wadis and valleys within the highlands are experiencing some danger due to the burying effect on their courses caused by the overblown sands.

Um Bayada Basin with its vast alluvial plain offers a good opportunity for development of irrigated agriculture for the production of cereals, vegetables, fruits and fodder crops for the whole region.

Tribal conflicts which tend to developed into local civil wars were mostly triggered by small conflicts on natural resources. 


\section{Recommendations}

1. A base line inventory is essential to delineate properly the degraded areas and provide reliable data on location, size, main land use types, water resources and potentiality of the land resources. Socioeconomic data on population, infrastructures and related aspects is as well essential.

2. Plans for combating desertification should be comprehensive and aim at balancing land exploitation and the ability of plants to regenerate and the soil to maintain itself and support plants.

3. Environmental programmes and projects for combating desertification (halting sand encroachment and rehabilitation of vegetation) should be structured to priorities actions for the affected areas. In this study it is proposed that northern and some central parts (P1) should be given high priority. South western and southern areas are given second and third priority (P2 and P3). Central southern parts south of Jebel Argud are given fourth priority and mountainous areas are given the last priority $\mathrm{P} 4$ and $\mathrm{P} 5$ ).

In some areas of $\mathrm{El} \mathrm{Meidob} \mathrm{region} \mathrm{the}$ situation of land degradation is relatively better than other degraded areas in North Darfur. These areas could be reserved and protected and managed with controlled utilization of its resources (grasses, trees) by local residents. Special programmes could be set with the help of the locals to improve and manage the land resources.

\section{References}

Akhtar, M.A., Mensching, H.G., Dominck, I. 1994. Methods Applied for Recording Desertification and their
Results from the Sahel Region of the Republic of Sudan. Desertification Control Bulletin, P25: PP 40-47.

Bakhit, A., Ibrahim, F.N. 1982. Geomorphological Aspects of the Process of Desertification in Western Sudan. Geojournal, 6(1): PP19-24.

Doka, A.M. 1980. Remote Sensing for Monitoring Soil Resources and Areas Affected by Desertification in Central Sudan: Proceedings of Sudan symposium and Workshop on Remote Sensing. Remote Sensing Institute. SDSU. USA.

Dregene, H.E. 1983a. Desertification in Arid-lands in :F. El-baz and I. H. A.,Hassan. (eds), Physics of Desertification. Martinus Nijhoff, Dordrecht, 4-34.

ECARP. 1976. Desert Encroachment Control and Rehabilitation Program.

El Hag, M.M. 1984. Study of Desertification Based on Land sat Imagery. 1984P. Faculty of Sciences. The State University of Ghent (Ph.D. Thesis).

FAP/UNFP. 1983, 1984. Provisional Methodology for Assessment and Mapping of Desertification PP 84. FAO, Rome.

Hellden, U. 1984. Drought Impact Monitors -A Remote Sensing Study of desertification in Kordofan, The Sudan. Lund's University. Nature geographic Institute, Papporter Och Notiser No 61pp.

Ibrahim, F. 1984. Ecological Imbalance in the Republic of the Suan - with reference to Desertification in Darfur. Druckhaus Bayreuth Vertagsgesellschaft $\mathrm{mbH}$. F. R. Germany.

Ibrahim, F. 1978. Anthropogenic Causes of Desertification in Western Sudan. Geojournal, 2(3): PP243-254.

Lillesand, T.M., Kiefer, R.W. 1994. Remote Sensing and Image Interpretation. $3^{\text {rd }}$ 
ed., - 750pp. New York, NY (Wiley).

Olson, L. 1985. An Intergrated Study of Desertification. Application of Remote Sensing, GIS and Special Models in Semi-arid Sudan. Malmoe, Uneversity of Lund. 170p.

Sabins, Floyd, J.R. 1986. Remote Sensing: Principles and Interpretation $2^{\text {nd }}$ edition. Free Man, W. H and Company, New York. P1-21.

UN. 1979. Report on the Expert Meeting on Methodology for Desertification Assessment and Mapping. Appendix D. Geneva.

UNCCD. 1994. United Nations Convention to Combat Desertification in those Countries Experiencing Serious Drought and/ or Desertification,
Particularly in Africa, UNCCD. UNCED. 1992. United Nations Conference on Environmental and Development, UNCED. Programmer of Africa for Sustainable Development. New York United Nations Department of Public Information.

Van der Kevie, W. 1975. Climatic Zones in the Sudan. Soil Survey Adminstration, Wad Medani, Sudan.

Warren, A. 1966. The Goz Region of Kordofan, Ph..D. Thesis, University of Cambridge, UK.

Yagoub, Y.A., Fadl Elmula, M. 1980. Application of Land sat for Deterioration of Land Resources and Desertification Monitoring, Proceeding of Sudan Symposium and Workshop on Remote sensing, USA.

\section{How to cite this article:}

El-Abbas. Doka M. Ali and Mahgoub Suliman Mohamedain. 2016. Assessment of Desertification at Umm Bayada Basin(Al Maleha Locality North Darfur State - Sudan). Int.J.Curr.Microbiol.App.Sci. 5(5): 94-108. doi: http://dx.doi.org/10.20546/ijcmas.2016.505.011 